\title{
Use of Chrysoperla carnea larvae to control whitefly (Aleyrodidea: Hemiptera) on tomato plant in greenhouse
}

\author{
Hamid Rehman ${ }^{1}$, Aslam Bukero ${ }^{1}$, Abdul Ghani Lanjar ${ }^{1}$, Lubna Bashir ${ }^{1}$, \\ Zainab Lanjar ${ }^{2}$ and Shahzad Ali Nahiyoon ${ }^{1 *}$ \\ 1. Department of Entomology, Sindh Agriculture University, Tandojam, 70060-Pakistan \\ 2. Department of Pharmacy, Faculty of animal Husbandry and Veterinary Sciences, Sindh Agriculture University, \\ Tandojam, 70060-Pakistan \\ *Corresponding author's email: Shezi_129@yahoo.com
}

Citation

Hamid Rehman, Aslam Bukero, Abdul Ghani Lanjar, Lubna Bashir, Zainab Lanjar and Shahzad Ali Nahiyoon. Use of Chrysoperla carnea larvae to control whitefly (Aleyrodidea:Hemiptera) on tomato plant in greenhouse. Pure and Applied Biology. Vol. 9, Issue 4, pp2128-2137. http://dx.doi.org/10.19045/bspab.2020.90227

Received: 01/02/2020 Revised: 29/05/2020

Accepted: 03/06/2020

Online First: 29/06/2020

\section{Abstract}

In the last ten years, whitefly has presented a serious risk to vegetables most commonly the tomatoes and natural products in the field. Another significant issue is associated with the pest management control system and insect preferences for the tomato plants. In these lines we investigate Predatory efficiency capability and capacity of Chrysoperla carnea with whitefly Bemisia tabaci in a greenhouse were study at Hyderabad, Pakistan. Larvae of Chrysoperla carnea were used against whitefly in a greenhouse. Adult, eggs and nymph of Bemisia tabaci is affected by Chrysoperla carnea. In this experiment used different numbers of larvae is attached to tomatoes plants to measure the efficiency of Chrysoperla carnea larvae. The overall mean population of whitefly indicates positive correlation with the number of larvae introduced. Highest overall mean whitefly population is observed in Un-Treated (13.11 1.614$)$ and (4.012 \pm 0.804$)$, the lowest count found in 10larvae/plant $(7.400 \pm 0.904)$ and $(1.363 \pm 0.561)$ for adult and nymph respectively. Up to $50 \%$ mortality is observed as compared to untreated plants. During this experiment, a strong negative correlation is observed between Chrysoperla carnea applied/plant and whitefly population (-0.808) and (-0.978) in adult and nymph respectively. Data also clearly showed decreased from start and after introduced Chrysoperla carnea larvae to tomato plants.

Keywords: Chrysoperla carnea; Bemisia tabaci; larvae; mortality; tomato

\section{Introduction}

The tomato, Lycopersicum Escolentum Mill, is a vital and generally utilized vegetable yield. It is extremely nutritive and heavenly; not very many vegetables can coordinate its nutritious esteem. Tomato is a standout amongst the most imperative vegetable products developed for its beefy leafy foods as vital business and dietary vegetable yield. It is a brief span product and gives a high return, it is imperative from the financial 
perspective and consequently, region under its development is expanding step by step [1]. A large number of pest is attacked on many vegetables in the greenhouse, resulted highly loss in yield [2]. In Egypt, currently up to $60 \%$ cucumber growing in the protected environment [3]. Biological control of major pests depending on specific predator [4]. Green lacewings (Neuroptera: Chrysopidae) are considered among the best generalist predators of aphids. Four arrivals of predator's 1st, 2nd and 3rd instar hatchlings were produced using the season of aphid's appearance on canola trim till its development at post daily interims. Utilization of chemicals has so far been viewed as the best methods for control of the vermin [5]. Since the utilization of pesticides is created with a few detriments, an organic control program in light of incorporated bug administration is a more judicious methodology [6]. Larvae of Chrysoperla carnea is feeding immature stage of whitefly [7]. The biological control is a strategy for controlling pest using common foes in horticulture that is a naturally solid and viable method for relieving vermin thickness [5]. The species in class Chrysoperla carnea have for some time been viewed as the most vital normally happening predators in numerous editing frameworks, including vegetables, natural products, nuts, fiber and scavenge crops, ornamentals, nursery harvests, and woodlands [8].

Green lacewing hatchlings are likewise known to eat a wide assortment of other delicate bodied arthropods including many aphid species and creepy crawlies by assaulting prey and sucking out their body liquids. It is a ravenous feeder on first instar larva of mealy bug, Phenacoccus solenopsis Tinsley [9]. The natural control by the utilization of predator Chrysoperla carnea has likewise picked up significance for pest administration in Pakistan. Some current examinations give a pivotal case of discharge locales for lacewings against Bemisia tabaci (Genn.) in cotton. Organic control by the utilization of predator Chrysoperla carneahas likewise picked up significance for bother administration in Pakistan. Some current examinations give an urgent case of discharge locales for lacewings against Bemisia tabaci (Genn.) in cotton [10]. The Chrysoperla carnea is a biological agent control Helicoverpa armigera (Hubner) in tomato [11]. The lacewings decreased the aphid populace on a few plants and their adequacy was $84 \%$. These investigations have demonstrated that nourishing and organization of lacewing for the control of its populaces as aphid predator is presently utilized as a part of coordinated administration of this irritation [12]. Chrysoperla carnea can be utilized as a viable natural control operator for effective usage of incorporated irritation administration program to lessen the utilization of bug sprays and spare outside trade spent on pesticides import. The productivity of lacewing to control nuisances can be influenced by numerous variables, including the utilization of various predator instars which might be an urgent factor in the accomplishment of augmentative organic control [8].

\section{Materials and methods Greenhouse}

The experiment was conducted in a greenhouse in Hyderabad, Sindh, Pakistan. The experiment was performed in a $3 \mathrm{~m} \times 5 \mathrm{~m}$ nursery. Initially, a $1 / 2^{\prime \prime}$ inch polyvinyl chloride (PVC) pipes and clear plastic $(0.05 \mathrm{~mm})$ was used to construct the greenhouse infrastructure (Fig. 1a). Besides, some bamboo was used to support the infrastructure. The environmental conditions inside the nursery were measured, using a hygrometer to control humidity, temperature and an air cooler as the evaporator. The environmental conditions used are as follows; temperature $\approx 28.42 \pm 2.96{ }^{\circ} \mathrm{C}$, 
humidity $\approx 32 \pm 3.48 \%$, photoperiod $\approx 10.55$

$\pm 0.18 \mathrm{~h}$, and light intensity $\approx 2400$ lux.

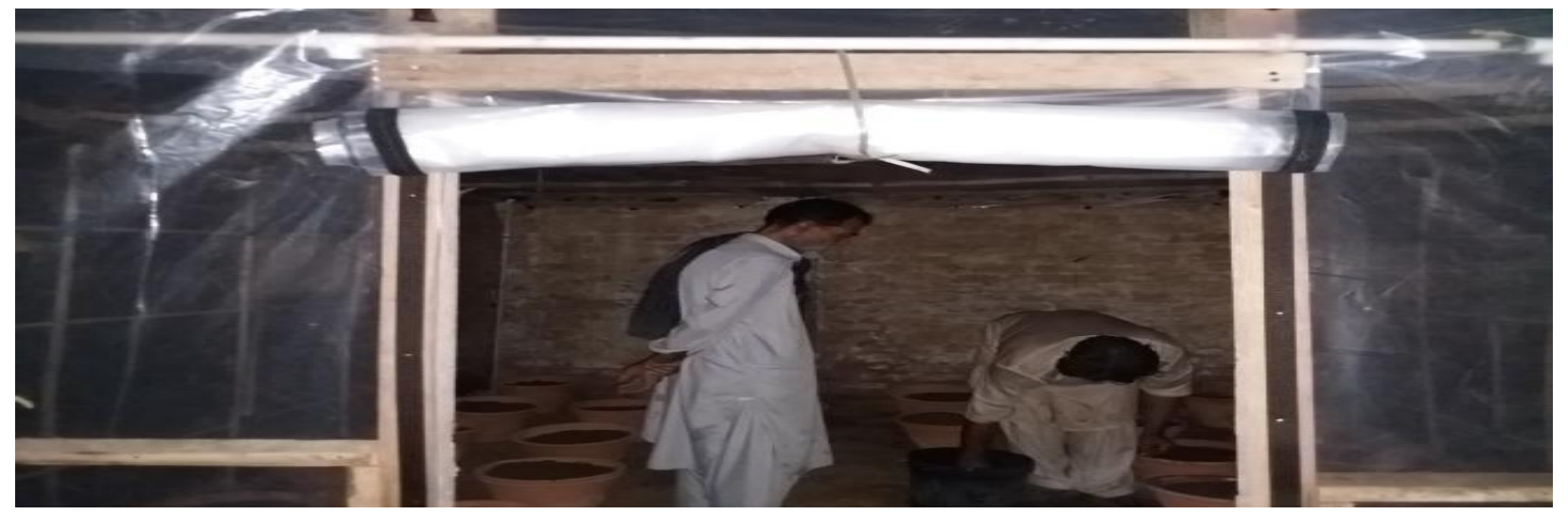

Figure 1a. Greenhouse

\section{Host plant selection}

The tomato plants were transplanted from the field into 35 plant mud pots (width $=30 \mathrm{~cm}$ ) in the nursery, while the selected 5 pots were exposed to treatment in this experiment. The plants were consistently watered twice a day. The mud pots Placed in Complete Randomized Design (CRD).

\section{Collection of Bemisia tabaci}

The whitefly adults were carefully collected from the field of cucumbers by utilizing a homemade suction apparatus (aspirator) (Fig. 1b). Only the adult whiteflies were used in this experiment. Approximately, 350-400 sets of whiteflies, which were gathered by the suction apparatuses, were released to the 35 tomato plants in the greenhouse. Complete Randomized Design (CRD) was used in this experiment. The counting for nymphs and adult whitefly population was started after week.

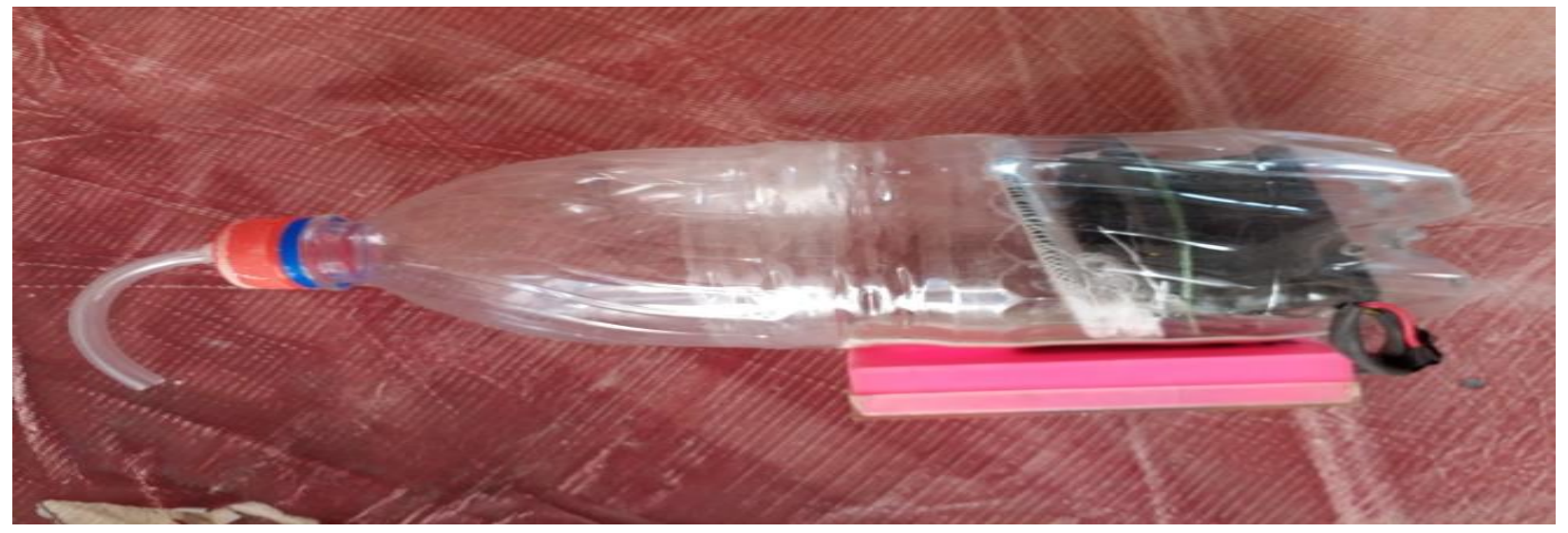

Figure 1b. Homemade Suction Apparatus (Aspirator)

\section{Chrysoperla carnea}

Chrysoperla carnea larvae obtained from the entomology lab of the Sindh Agriculture University, Tando Jam. Larvae of Chrysoperla carnea were transferred gently to the greenhouse with muslin black cloth attached to the plant by a pin. Chrysoperla carnea attached to plants in 2, 4, 6,8,10/plant (Fig 1c). 


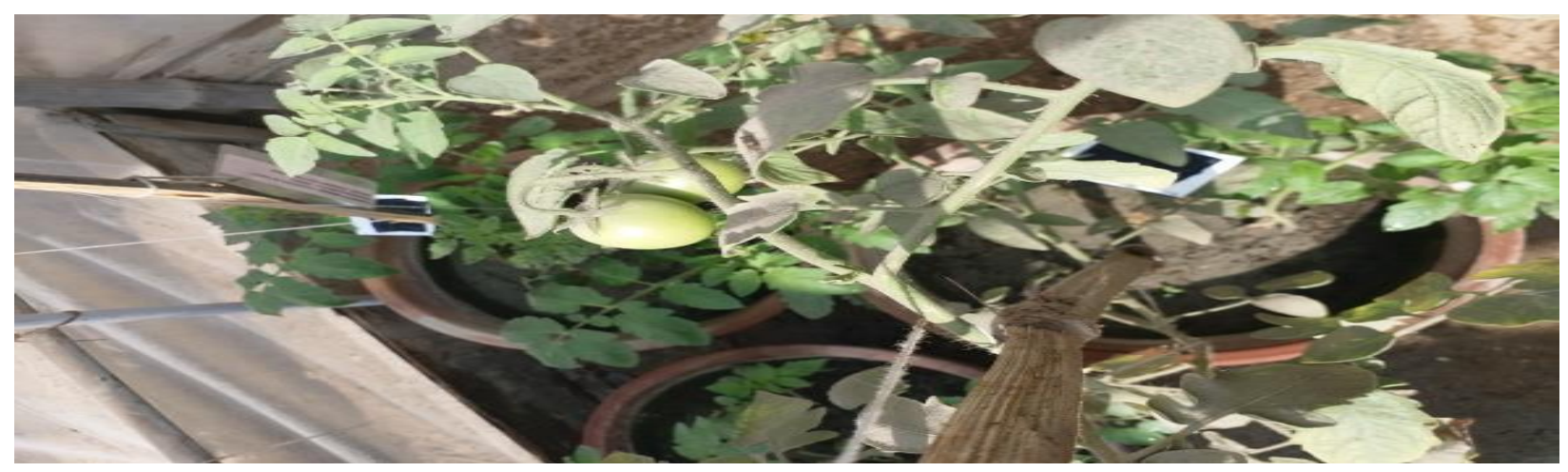

Figure 1c. Chrysoperla carnea attached to tomato plant in greenhouse

\section{Observations}

Tomatoes plants pots are placed in Complete Randomized Design in a greenhouse, 5 plats/treatment. There were 6 treatments applied, $\quad \mathrm{T} 1=2 \quad$ Larvae/Plant, $\quad \mathrm{T} 2=4$ Larvae/Plant, $\quad \mathrm{T} 3=6 \quad$ Larvae/Plant, $\quad \mathrm{T} 4=8$ Larvae/Plant, $\quad$ T5=10 Larvae/Plant andT6=UN-TREATED. 10 leaves were randomly selected from each treatment to count the number of whiteflies. The initial data was taken after a week of the release of Chrysoperla carnea larvae in the greenhouse. The data was taken twice a week up to four weeks.

\section{Data analysis}

The results were analyzed using Statistics 8.1. The data were subjected to analyze variations used (ANOVA).

\section{Results}

In adult, high mortality of whitefly was observed. The number of Chrysoperla carnea larvae applied to the per plant was strongly negative correlation r-value (-0.808) to whitefly population (Fig. 2). The lowest count was observed in $\mathrm{T} 1$ and the highest number found in untreated. $50 \%$ whitefly mortality observed in all treatments accepted $\mathrm{T}=4$ (4 larvae/plant), $40 \%$ mortality with an overall mean $(9.30 \pm 0.98)$ (Fig. 3). During adult count from lowest to high recorded, $\mathrm{T} 1=(6.70 \pm 1.03), \quad \mathrm{T} 2=(7.42 \pm 1.15), \quad \mathrm{T} 3=$ $(7.96 \pm 1.04), \quad \mathrm{T} 5=\quad(8.20 \pm 1.04), \quad \mathrm{T} 4=$ $(9.30 \pm 0.98)$ and in highest count found in $\mathrm{T} 6=(13.92 \pm 1.61)$ (Table 1). During the experiment, Chrysoperla carnea larvae mortality also observed but very low. In nymph, there are three groups in which mean are not significantly different from each other.

Lowest count observed in $\mathrm{T} 1=(10$ larvae/plant) with (1.363 \pm 0.561$)$ and highest overall mean population was observed in untreated (4.012 \pm 0.804$)$ (Table 2). Very strong negative correlation r-value $(-0.978)$ is observed in between Chrysoperla carnea applied and whitefly nymph (Fig. 2). In nymph from lowest to highest position possesses by $\mathrm{T} 1=(1.363 \pm 0.561)<\mathrm{T} 2=$ $(1.825 \pm 0.539)<\mathrm{T} 3=(1.86 \pm 0.63)<\mathrm{T} 4=$ $(2.725 \pm 0.646)<\mathrm{T} 5=(3.275 \pm 0.849)<\mathrm{T} 6=$ untreated. 


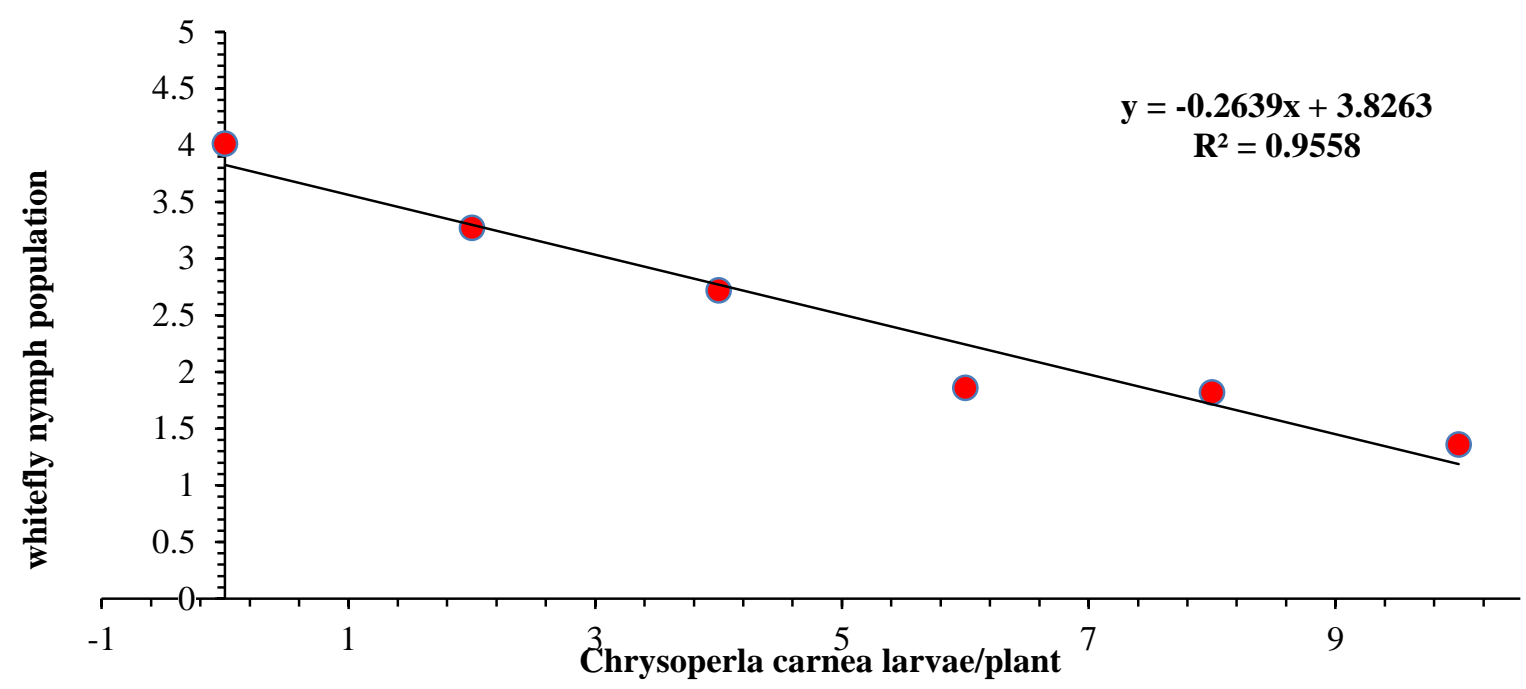

Figure 2. Correlation between Chrysoperla carnea larvae/plant and whitefly nymph population

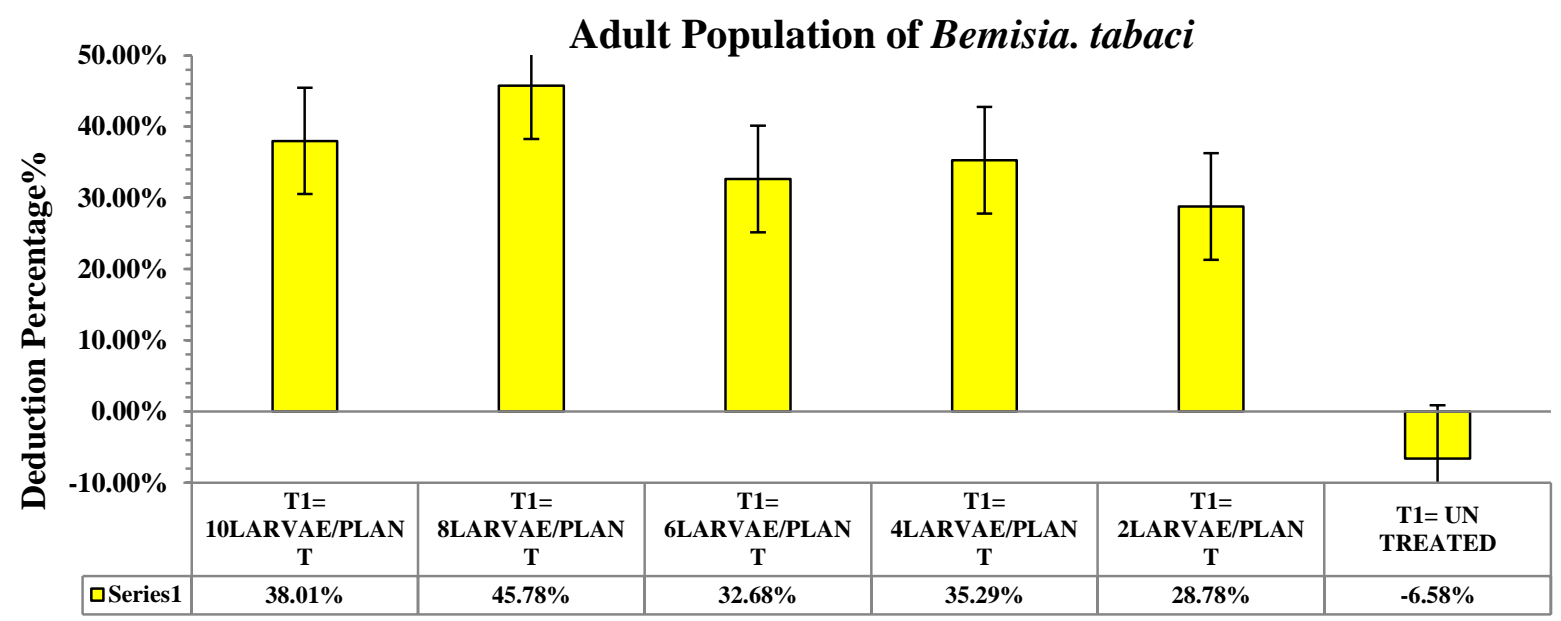

Figure 3. Deduction in adult population of Bemisia tabaci after treated with Chrysoperla. carnea

Table 1. Impact of Chrysoperla carnea on adult population of Bemisia. tabaci

\begin{tabular}{|c|c|c|c|}
\hline Treatment & $\begin{array}{c}\text { Pre Treatment } \\
\text { Population (Adult) }\end{array}$ & $\begin{array}{c}\text { Post Treatment } \\
\text { Population (Adult) }\end{array}$ & $\begin{array}{c}\text { \% Adult Population } \\
\text { Change }\end{array}$ \\
\hline T1= 10LARVAE/PLANT & $11.20 \pm 1.746$ & $7.400 \pm 0.904 \mathrm{c}$ & $38.01 \%$ \\
\hline T1= 8LARVAE/PLANT & $13.20 \pm 1.685$ & $7.513 \pm 1.070 \mathrm{c}$ & $45.78 \%$ \\
\hline T1= 6LARVAE/PLANT & $12.00 \pm 1.937$ & $8.610 \pm 1.070 \mathrm{bc}$ & $32.68 \%$ \\
\hline T1= 4LARVAE/PLANT & $14.10 \pm 1.249$ & $9.725 \pm 1.077 \mathrm{~b}$ & $35.29 \%$ \\
\hline T1= 2LARVAE/PLANT & $11.00 \pm 1.536$ & $8.350 \pm 1.085 \mathrm{bc}$ & $28.78 \%$ \\
\hline T1= UN TREATED & $12.30 \pm 1.630$ & $13.11 \pm 1.614 \mathrm{a}$ & $-6.58 \%$ \\
\hline
\end{tabular}

Overall mean in same column followed by same letter are not significantly different using General AOV/AOCV LSD $(\alpha=0.05)$ 
Table 2. Effect of Chrysoperla. carnea on nymph population of Bemisia. tabaci on tomato

\begin{tabular}{|c|c|c|c|}
\hline Treatment & $\begin{array}{c}\text { Pre Population } \\
\text { (Nymph) }\end{array}$ & $\begin{array}{c}\text { Post Population } \\
\text { (Nymph) }\end{array}$ & $\begin{array}{c}\text { \% Nymph } \\
\text { Population Change }\end{array}$ \\
\hline T1= 10LARVAE/PLANT & $3.000 \pm 0.720$ & $1.363 \pm 0.561 \mathrm{c}$ & $57.37 \%$ \\
\hline T1= 8LARVAE/PLANT & $4.400 \pm 1.002$ & $1.825 \pm 0.539 \mathrm{c}$ & $61.09 \%$ \\
\hline T1= 6LARVAE/PLANT & $2.910 \pm 0.720$ & $1.860 \pm 0.630 \mathrm{c}$ & $40.03 \%$ \\
\hline T1= 4LARVAE/PLANT & $3.920 \pm 0.547$ & $2.725 \pm 0.646 \mathrm{~b}$ & $34.78 \%$ \\
\hline T1=2LARVAE/PLANT & $4.200 \pm 0.800$ & $3.275 \pm 0.849 \mathrm{~b}$ & $26.64 \%$ \\
\hline T1= UN TREATED & $3.900 \pm 1.308$ & $4.012 \pm 0.804 \mathrm{a}$ & $-2.87 \%$ \\
\hline
\end{tabular}

Overall mean in same column followed by same letter are not significantly different using General AOV/AOCV LSD $(\alpha=0.05)$

The Chrysoperla carnea efficiency is assessed on the bases of change in population percentage $(\%)$ of Bemisia. tabaci. In the adult population of Bemisia. tabaci, the \% change in population is recorded as, $\mathrm{T} 1$ $(38.01 \%)$, T2 $(45.78 \%)$, T3 $(32.68 \%)$, T4 $(35.29 \%)$, T5 $(28.78 \%)$ and T6 $(-6.58 \%)$ (Fig. 3). The outcomes adjusted the Chrysoperla carnea impact on the density of Bemisia tabaci. In the contrary, the information recorded an increase in population density of Bemisia tabaci in the untreated plot. In nymphal population of Bemisia tabaci, data recorded in all treatment as, T1 (57.37\%), T2 (61.09\%), T3 (40.03\%), T4 (34.78\%), T5 (26.64\%) and T6 (-2.87\%) (Fig. 4).

In all treatment just one negative pursuing recorded which demonstrated expanded in population density of whitefly in T6=untreated plot respectively (Fig. $2 \& 5$ ).

As percentage (\%) change in adult Bemisia tabaci density in all treatment from high to low lineup as, Treatment $2>$ Treatmen $1>$ Treatmen4 > Treatmen3 > Treatmen5> Treatmen6. In nymph density of whitefly population \%change is lineup as, Treatment 2 $>$ Treatmen $1>$ Treatmen3 > Treatmen4 > Treatmen $5>$ Treatmen 6 . Result revealed the essentialness of Chrysoperla carnea as organic control specialist. Information recommended that high numbers of Chrysoperla carnea released to expand the proportion of effective control of whitefly.

Release of Chrysoperla carnea is significantly decreased whitefly population, the result indicates $(\mathrm{DF}=420 \quad \mathrm{P}<0.05)$ between all 5 treatments. The result showed that in all experiment in start number of whitefly is high and decreased at the end (Table 1).

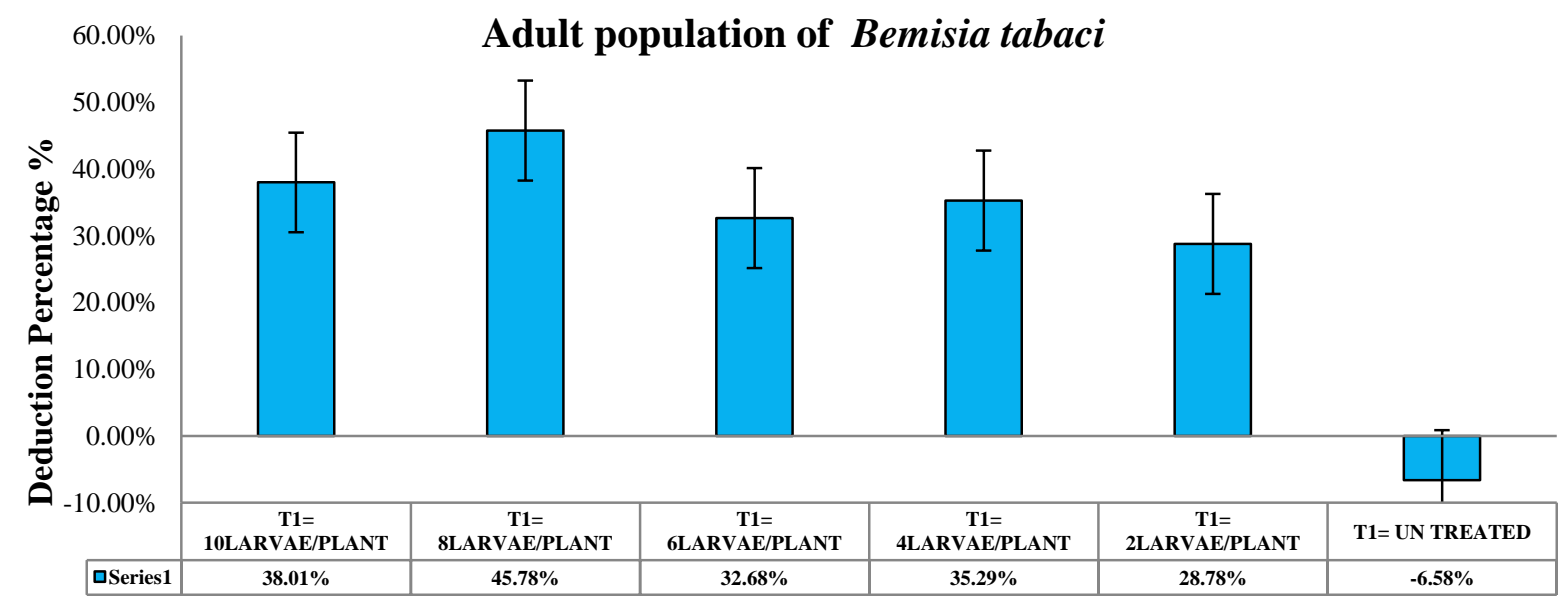

Figure 4. Deduction in nymph population of Bemisia tabaci after treated with Chrysoperla carnea 


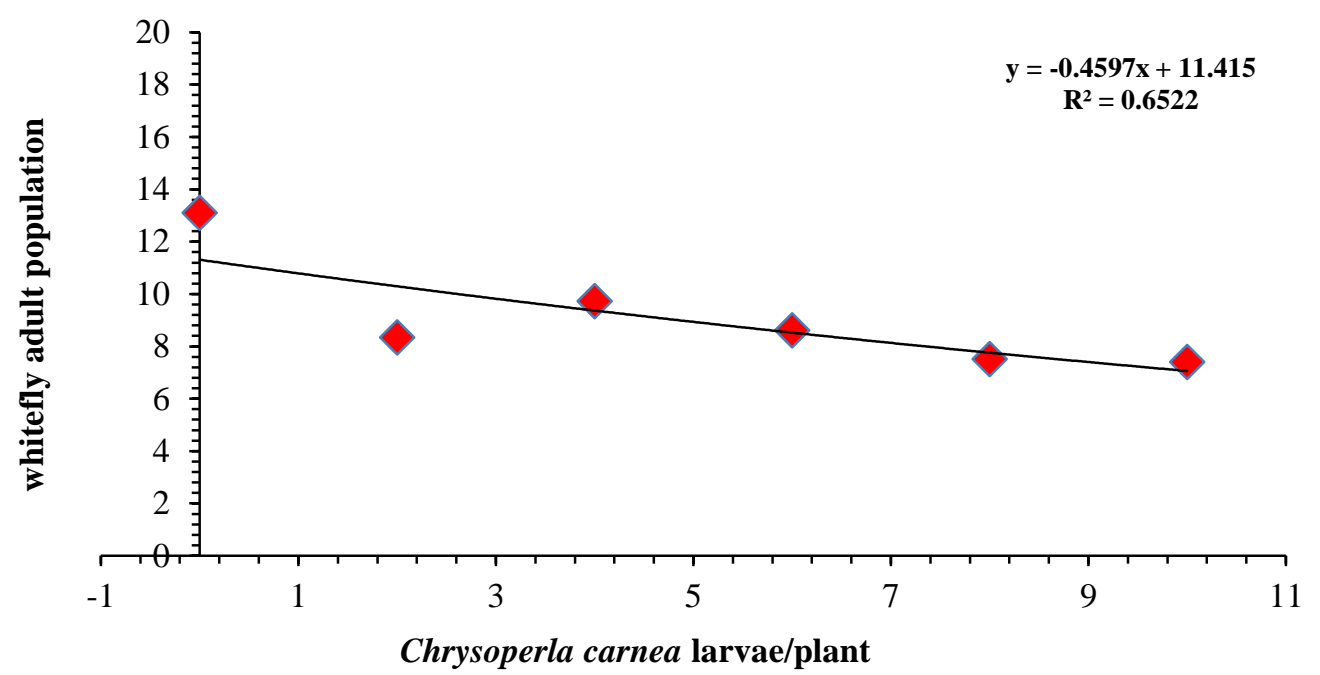

Figure 5. Correlation between Chrysoperla carnea larvae/plant and whitefly adult population

\section{Discussion}

Observed that Chrysoperla carnea larvae feed on all instar of whitefly nymph, eggs and it is observed that the larvae preferred adult of whitefly as well which indicates that Chrysoperla carnea larvae disturbed or effect all life cycle of Whitefly highly mortality in immature stage really affect whitefly population and also improve food availability for larvae of Chrysoperla carnea. Mortality in immature stages of Bemisia tabaci from various sources in cotton, observed from many years more successfully control pest population below economic levels [13]. Also same reported in immature E. Transvena within 4th instar Bemisia tabaci in laboratory condition [14]. Chrysoperla carnea also oviposit eggs, eggs were attached leaves with stalk but eggs and oviposition were not evaluated in this experiment. [15] reported, in Indian Punjab Chrysoperla carnea laid eggs on cotton in the growing season. pursued by [16]. The development period of Chrysoperla Carnea is prolonged as compared to the lab. Same finding reported by [17]. The development period of Chrysoperla carnea is long because of lessening in nourishment accessibility of food and utilization too [17].
Chrysoperla carnea growth period has lasted for $19.15,19.35,20.15,20.60$, and 20.50 days till to start feeding [18].

This is due to because of a lack of food availability of food and environmental condition affect the development of Chrysoperla carnea. The success of released biological control agents or mass-reared natural enemies in any system required more attention, for example, monitoring of environment and take care of food availability as well [19, 20].

Natural enemies decreased population of whitefly in every regarded plot as compare to un-treated [21]. As per our information as a percentage change in the population of Bemisia tabaci, high declined saw up to $45 \%$ and $60 \%$ in adult nymph population respectively in the greenhouse. Same discoveries reported by [21] that, $65.12 \%$ and $4 \%$ diminished in mites after released of Chrysoperla carnea and Trichogramma respectively. Additionally, detailed $70.86 \%$ in aphid and $80 \%$ decreased in the whitefly population as compared to un-treated plot. Comparable findings reported by [7] that Chrysoperla carnea is a major predator of whitefly and aphid. Chrysoperla carnea 
devoured 510 nymphs of whitefly [22]. In contrary, Adly [23] detailed that releasing of predators high criticalness responsible of the pest population, yet also additionally referenced a challenge of pest which predator not known or find and a field whereas regular adversaries not built up. [24] Reported that Chrysoperla carnea was discovered dynamic predator against pest particularly whitefly. Same revealed by [25] in the association of pest and predators and pursued by [26]. The same perception reported in the pest of cotton [27]. We found Chrysoperla carnea is most classical control natural agent against whitefly in the greenhouse. Natural enemies are the main component of IPM from very older ages. On the other hand, very classical define thought is biological control not given position as they have, in control of arthropod pest suppression [13, 28, 29]. DeBach and Rosen [30] define biological control with these words that biological control as engineered the environment to favour biological control agents.

Experiment finding indicates that Chrysoperla carnea is more effective in the greenhouse for control of whitefly with some traits like food availability of food and environmental condition, some reported, that Chrysoperla carnea was successfully used in IPM with some possible traits by [31]. The success of predator and natural enemies accommodating in diminished of pesticide was detected [18].

\section{Conclusion}

The finding of this experiment has proven that the Chrysoperla Carneais an effective biological control agent for control whitefly in the greenhouse. Selection of the biological control agent, release and monitoring consistently. In conclusion, Chrysoperla Carnea larvae were very positively decreased the damage of whitefly and also another insect pest as well. It is also concluded that larvae and adult green lacewing (Chrysoperla carnea) are both are predatory on all stages of Bemisia tabaci.

\section{Authors' contributions}

Conceived and designed the experiments: $\mathrm{R}$ Hamid, A Bukero \& AG Lanjar, Performed the experiments: R Hamid, Analyzed the data: R Hamid, A Bukero \& AG Lanjar, Contributed materials/ analysis/ tools: B Lubna, L Zainab, SA Nahiyoon, Wrote the paper: R Hamid, B Lubna \& SA Nahiyoon.

\section{References}

1. Kevany BM, Taylor MG \& Klee HJ (2008). Fruit-specific suppression of the ethylene receptor Leetr4 results in earlyripening tomato fruit. Plant Biotechnol $J$ 6(3): 295-300.

2. Saad HM (2002). Economics of the integrated pest management of certain insect and animal pests on most important vegetable crops production under plastic greenhouses. Arabic 4(3): 219-297.

3. El-Zawely FE \& El-Sawy NH (2007). Effect of plastic tunnel size on production of cucumber in delta of Egypt. Appl Ecol and Environ Res 5(2): 11-24.

4. Hoy MA (1994). Parasitoids and predators in management of arthropod pests. Intro to Ins Pest Manag 4(1): 129198.

5. Sarwar M (2014). The propensity of different larval stages of lacewing Chrysoperla carnea (Stephens), (Neuroptera: Chrysopidae) to control aphid Myzus persicae (Sulzer), (Homoptera: Aphididae) evaluated on Canola Brassica napus L. Songklanakarin $J$ of Sci and Technol 36(2): 143-148.

6. Ahmad M, Arif MI \& Naveed M (2010). Dynamics of resistance to organophosphate and carbamate insecticides in the cotton whitefly Bemisia tabaci (Hemiptera: 
Aleyrodidae) from Pakistan. $J$ of Pest Sci 83(4): 409-420.

7. Jokar M \& Zarabi M (2012). Surveying effect kind of food on Biological parameters on Chrysoperla carnea (Neuroptera: Chrysopidae) under laboratory Conditions. Egyptian Acad J of Biol Sci A, Entomol 5(1): 99-106.

8. Tauber MJ, Tauber CA, Daane KM \& Hagen KS (2000). Commercialization of predators: recent lessons from green lacewings (Neuroptera: Chrysopidae: Chrosoperla). American Entomol 46(1): 26-38.

9. Khan HA, Sayyed AH, Akram W, Razald S \& Ali M (2012). Predatory potential of Chrysoperla carnea and Cryptolaemus montrouzieri larvae on different stages of the mealybug, Phenacoccus solenopsis: A threat to cotton in South Asia. J of Ins Sci 12(1): 145-147.

10. Zia KH, Hafeez FA, Khan RR, Arshad MU \& Naeem-Ullah UN (2008) effectiveness of Chrysoperla carnea (Stephens), (Neuroptera: Chrysopidae) on the population of Bemisia tabaci (Homoptera: Aleyrodidae) in different cotton genotypes. J Agric Soc Sci 4(1): $112-6$.

11. Usman $\mathbf{M}$, Inayatullah $\mathrm{M}$, Usman $\mathrm{A}$, Sohail K \& Shah SF (2012). Effect of egg parasitoid, Trichogramma chilonis, in combination with Chrysoperla carnea and neem seed extract against tomato fruit worm, Helicoverpa armigera. Sarhad J Agric 28(2): 253257.

12. Messina FJ \& Sorenson SM (2001). Effectiveness of lacewing larvae in reducing Russian wheat aphid populations on susceptible and resistant wheat. Biol Cont 21(1): 19-26.

13. Naranjo, SE (2001). Conservation and evaluation of natural enemies in IPM systems for Bemisia tabaci. Crop Prot, 20(9): 835-852.

14. Kapadia MN \& Puri SN (1990). Feeding behaviour of Chrysoperla carnea (Stephens) on the parasitized pupae of Bemisia tabaci (Gennadius). Entomon 15(4): 283-284.

15. Mannan VD, Varma GC \& Brar KS (1995). Seasonal fluctuations and host predator relationship of Chrysoperla carnea (Stephens), (Chrysopidae: Neuroptera). Indian J of Ecol 22(1): 2126.

16. Mallah GH, Korejo AK, Soomro AR \& Soomro AW (2001). Population dynamics of predatory insects and biological control of cotton pests in Pakistan. J Biol Sci 1(24): 5-248.

17. Salama HS, Zaki FN \& Sharaby AF (1982). Effect of Bacillus thuringiensis Berl. on parasites and predators of the cotton leaf worm Spodoptera littoralis (Boisd.). Zeitschrift Für Angewandte Entomol 94(15): 498-504.

18. Viji CP \& Gautam RD (2005). Feeding potential and cost of production of green lacewing, Chrysoperla carnea (Stephens) on alternate hosts. Ann of Plant Prot Sci 13(2): 271-274.

19. Van den BR \& Telford AD (1964). Environmental modification and biological control. DeBach, Paul Biol Control of Ins Pests and Weeds 4(1): 219-258.

20. Gurr GM \& Wratten SD (1999). Forum' Integrated biological control': A proposal for enhancing success in biological control. Inter $J$ of Pest Manag 45(2): 81-84.

21. Mari, JM (2012). Use of Chrysoperla carnea and Trichogramma chiloni (Ishii) on the population of insect pests in chilli ecosystem. In Proc of the Ann Inter Conf, Syiah Kuala Uni Life Sci \& Engin Chapter 2(1): 314-319 
22. Gautam RD \& Tesfaye A (2002). Potential of green lacewing, Chrysoperla carnea (Stephens) in crop pest management. New Agric 13(2): 147-158.

23. Adly D (2016). Use of Predators for Controlling the Whitefly, Bemisia tabaci Genn. and the Two Spotted Spider Mite, Tetranychus urticae Koch., in Cucumber Greenhouses in Egypt. Egyptian J of Biol Pest Control 26(4): 214-219.

24. Messelink GJ, Bennison J, Alomar O, Ingegno BL, Tavella L, Shipp L \& Wäckers FL (2014). Approaches to conserving natural enemy populations in greenhouse crops: current methods and future prospects. Biol Control 59(4): 377-393.

25. Sewify GH, El-Arna'outy SA \& Belal MH (1996). The effect of cotton late planting on population densities of sucking insects and their associated predators in Giza region, Egypt. Bull of Faculty of Agric, Cairo Univ (Egypt).

26. Center SR (2008). Presence and abundance of different insect predators against sucking insect pest of cotton. $J$ Entomol 5(1): 31-37.

27. Abou-Elhagag GH (1998). Seasonal abundance of certain cotton pest and their associated natural enemies in Southern Egypt. Assiut $J$ of Agric Sci 29(1): 253-267.

28. Ehler L (1998). Conservation biological control: past, present, and future. In Conservation Biol Cont, pp 1-8. Academic Press.

29. Landis DA, Wratten SD \& Gurr GM (2000). Habitat management to conserve natural enemies of arthropod pests in agriculture. Ann Rev of Entomol 45(1): 175-201.

30. DeBach RP \& Rosen D (1991). Biological Control By Natural Enemies. CUP Archive.

31. Grafton-Cardwell, EE \& Hoy MA (1985). Intraspecific variability in response to pesticides in the common green lacewing, Chrysoperla carnea (Stephens), (Neuroptera: Chrysopidae). Hilgardia 53(6): 1-32. 